\title{
A HYPOTHETICAL IMMUNEMEDIATED UNIFYING MECHANISM FOR THE HOLMES-ADIE SYNDROME
}

\author{
C. M. DE CASTRO COSTA* - J. VAN HEES** - D. C. DO VALE***
}

SUMMARY - The Holmes-Adie syndrome consists of pupillotonia, arreflexia and autonomic dysfunction. Some explanations for these different symptoms have been attempted, centred upen neuropathological and electrophysiological findings. A hypothetical immunemediated mechanism, as in the Guillain Barré syndrome, is presented in this paper for explaining the three chief symptoms of the syndrome.

\section{Cma imune-hipótese unifieante para o mecanismo da síndrome de IIolnes-Adie.}

RESUMO - A sindrome de Holmes-Adie consiste de pupila tônica, arreflexia patelar e disfunção autonômica. As explicações desses diferentes sintomas têm-se baseado em achados neuropatológicos e eletrofisiológicos. Neste trabalho apresenta-se uma hipótese inunológica para a fisiopatogenia da sindrome, de modo semelhante à da sindrome de Guillain-Barré.

The Holmes-Adie syndrome is clinically characterized by the presence of a uni or bilateral tonic pupil which is unresponsive to light but responsive to accomodation, and an absence of patellar and Achilles reflexes 6,8. Morcover, anhydrosis and hyperthermia, as signs of autonomic dysfunction, have also been described in this syndrome 9 . Its etiology is anknown, but a viral or post-viral origin has been mentioned 3,4 .

Up to now some mechanisms have been described to explain the two basic elements of the syndrome without however establishing a single mechanism for both. The explanations are centred upon two sites: the ciliary and spinal ganglia and the iris sphincter. As to the ganglia neurons, Harriman and Garland 3 and Ulrich 11 have shown that the basic mechanism for explaining the tonic pupil and arreflexia lies on a degeneration of neurons of the ciliary and spinal ganglia which leads to a partial denervation of the iris sphincter muscle and to the impairment of the reflex arch. Lowenfeld and Thompson 4 proposed that the tonic pupil may be explained by a misregeneration of parasympathetic fibers, originally supplying the ciliary muscle to postganglionic fibers destined to the iris sphincter by a cross-talk mechanism. Adie 1 had already mentioned such possibility and that, this phenomenon, accompanied by denervation supersensitivity of the iris sphincter muscle, could explain the tonic pupil. A greater response to near stimuli than to light stimuli and the delay in iris sphincter contraction and relaxation may occur by release of acetylcholine from the neurovascular junction of the ciliary muscle followed by a transaquecus diffusion to receptor sites on denervation supersensitive iris sphincter muscle 14. As to absence of stretch reflexes, Hardin and Gay 2 and McComas and Tayan 7 made some electrophysiological studies and observed severely depressed or absent $H$ waves after stimulation of the popliteal nerve in patients with Adie's syndrome. They interpreted the finding as indicative of a reduction of transmitter substance at the synapsis 7 or as

* Departamento de Fisiologia e Farmacologia, Universidade Federal do Ceará (UFC); ** Gasthuisberg-Afdeling Neurologie, Leuven (Belgium); ** Fospital das Clínicas, UFC. 
a result of a lesion of interneurons excitatory to the alpha motor neurons $\mathbf{2}$, the iast notion having been criticized by Martinelli et al.5.

All these notions have brought important contribution to the understanding and possible therapeutic assays for this syndrome 13. Some questions however still remain to be answered. The misregeneration and denervation supersensitivity may explain the phenomenon of tonic pupil but they do not help explaining the arreflexia. On the other side the electrophysiological findings do not explain the tonic pupil. The degeneration of the ciliary and spinal ganglia could give an explanation for both process but it seems that the cases studied from neuropathological point of view seem to be in a late stage of the evolution of the disease and the degeneration of the neurons: could be a phenomenon, which explains the irreversibility of the process. The phenomenon of misregeneration can leads us to suppose that, in the initial phase, the neurons of the gangiia are not yet degenerated so that segmental and axonal degenerative phenomenon could take place, the neurons being for same time spared. In this order of evolution one may suppose that the initial lesion would impair the myelin (segmental demyelination). As to the site of this lesion, Spector and Bachman 9 have mentionned that clinical, experimental and autopsy studies have shown that Adie's tonic pupil results from a postganglionic lesion of the parasympathetic pathway to the pupil.

It is known that the preganglionic and postganglionic parasympathetic fibers to the ciliary muscle and iris sphincter nerve are small myelinated fiber whereas in other nerves the postganglionic parasympathetic fibers are unmyelinated fibers of $C$ type 10.12 . In the spinal nerves, the fibers implicated in the reflex phenomenon are as well myelinated ones. The initial demyelination could then explain the phenomenon of the denervated iris sphincter and impairment of transmission of impulses in the spinal nerve fibers, explaining this way the tonic pupil and arreflexia. The subsequent degeneration of the axon and of the ciliary and spinal ganglia would make these symptoms definitive and irreversible.

This demyelinating process might be hypothetically induced by a virus with a delayed hypersensitivity reaction against the myelin, so as in the polyradiculoneuropathy (Guillain-Barré syndrome), where there is a segmental demyelination, and in severe cases, an extensive axonal degeneration that may result in chromatolysis of motor and sensory neurons, denervation of muscle and poor functional recovery. Moreover, the autonomic dysfunction described in the Holmes-Adie syndrome may perhaps be described by the same mechanism.

If this hypothesis proves to be true, it may give way to immunological approach to the Holmes-Adie syndrome, and clinical studies would lead to possible precocious therapeutic measures which could stop the process in a reversible phase.

\section{REFERENCES}

1. Adie WJ - Tonic pupils and absent tendon reflexes. Brain 55:98, 1932.

2. Hardin WB, Gay AJ — The phenomenon of benign arreflexia: review of the Holmes-Adie syndrome and a study of the Achilles reflex. Neurology 15:613, 1965.

3. Harriman DGF, Garland H - The pathology of Adie's syndrome. Brain 91:401, 1968.

4. Lowenfeld IE, Thompson HS - The tonic pupil: a reevaluation. Am J Ophthalm 63:46, 1967 .

5. Martinelli P, Montagna P, Gabellini AS - Holmes-Adie-syndrome (Letter). J Neurol Neurosur Psychiat 43:1147, 1980.

6. Massey EW - Pupillary disautonomia and migraine: is Adie's pupil caused by migraine? Headache $21: 143,1981$.

7. McComas AJ, Payan $J$ - Motoneurone excitability in the Holmes-Adie syndrome. In Andrew BL (ed): Control and Innervation of Skeletal Muscle. Livingstone, Edinburg, 1966. 
8. Pasco M - Das Adie-syndrome: Betrachtungen uber zweì Falle. Klin Mbl Augenheilk $176: 835,1980$.

9. Spector RH, Bachman DL - Bilateral Adie's tonic pupil with anhidrosis and hyperthermia. Arch Neurol 41:342, 1984.

10. Trautmann JC - Disease of the 1hird, fourth and sixth cranial nerves. In Dyck PJ. Thomas PK, Lambert EH (eds): Peripheral Neuropathy. Saunders, Philadelphia, 1975, vol 1, por 515, 1975 ,

11. Ulrich J - Morphological basis of Adie's syndrome. Eur Neurol 19:390, 1980.

12. Warwick R, Williams PL - Neurologia. In Gray Anatomia. Ed 35. Guanabara Koosan. Rio, 1979, yg 941, 1001.

13. Wirtschafter JD, Herman WK - Low concentration eserine therapy for the tonic pupil (Adie) Syndrome. Ophtalmology 87:10\$3, 1980.

14. Wirtschafter JD, Volk CR, Sawchuk RJ - Transaqueous diffusion of acetylcholine to denervated iris sphincter muscle: a mechanism for the tonic pupil syndrome (Adie syndrome). Ann Neurol 4:1, 1978. 